Original Research Article

\title{
Impact of rural transportation networks on farmers' income in Ilaje Local Government Area of Ondo State, Nigeria
}

\section{Oluwatoyin Olagunju}

Department of Agricultural Economics and Extension, Faculty of Agriculture, Adekunle Ajasin University, Akungba-Akoko, Ondo State, Nigeria

\section{Correspondence to:}

O. Olagunju, Department of Agricultural Economics and Extension, Faculty of Agriculture, Adekunle Ajasin University, P.M.B. 001, Akungba-Akoko, Ondo State, Nigeria, e-mail: toyinolagunju01@gmail.com

\begin{abstract}
This study examined how the nature of rural transportation networks affects the income of local farmers. The study involved arable crop farmers in the Ilaje local government area of Ondo State, Nigeria. A structured interview was used to gather information from a total of 120 farmers in rural communities across the local government using a two-stage random sampling technique. Descriptive statistics and inferential statistics such as chi-square and Pearson Product Moment Correlation (PPMC) were used to analyse the data. The study revealed that farmers' poor nature of transportation networks has a negative impact on their income. Gender $\left(\chi^{2}=6.472\right)$ and marital status $\left(\chi^{2}=9.745\right)$ positively influenced income generated by farmers at $p<0.05$. Additionally, there was a moderate and significant correlation between transportation systems used $(r=0.705, p<0.05)$, the perceived impact of rural transport $(r=0.267, p<0.05)$, and the farmers' income on agricultural activities. The results have shown that the serious constraints faced by the farmers are high cost of transportation which has a great influence on their generated income. The study allows to conclude that the nature of transportation networks available in the communities under study has a significant impact on the level of income to be realised by farmers. The construction, development, and provision of more rural transport networks would not only boost the standard of living and reduce transport costs of the rural poor but could also be a solution for the prolonged deplorable and worsening situation of rural roads in the country.
\end{abstract}

Keywords: Farmers; impacts; income; socio-economic factors; vehicles; boats; canoes

\section{INTRODUCTION}

Rural road networks are considered to be essential for the economic development of any country as well as the growth of rural areas (Adefalu et al., 2016). Many individuals and agencies have acknowledged the development of rural roads as a tool to lessening the effect of poverty on the people living in rural areas of underdeveloped countries. The condition of rural roads in Nigeria has constituted contemporary issues that have affected agricultural activities in the country (Agbigbe, 2016). However, commitment to the development of rural roads network has enhanced steady progress and an increase in agricultural production of the rural farmers which is crucial to raise sustainable income for the rural poor and economic development of many countries (Amare et al., 2017). Presently, agriculture has been considered to be a strong mainstay of the Nigerian economy with a contribution of almost $40 \%$ to the GDP and creates close to $70 \%$ of the entire workforce (Abubakar et al., 2018; Osabohien et al., 2019).

\section{(C) AUTHOR 2022.}

This work is licensed under the Creative Commons Attribution-NonCommercial-NoDerivs 4.0 License (https://creativecommons.org/licenses/by-nc-nd/4.0/) 
Roads in rural areas are very important for the economic and socio-political situation of rural communities in Nigeria. They give opportunity to rural populations to access education, health facilities, farms, markets, and other communities in rural areas (Afolabi et al., 2018). Bad roads have negative consequences for the aspects of improving agricultural activities especially in the areas of social and economic development, since the economy of the rural areas relies on the farmers (Ikejiofor and Ali, 2014). Omollo (2015) indicated that restricted mobility in rural communities regularly serves as an impediment to introducing innovation and strategies, increases the cost of production and marketing prices, decreases spatial connectivity, and reduces access to education and health facilities. Also, flexibilities are restricted and create disaffection (Nduati, 2017). Studies by Archer and Nkambwe (2011) also used various indices to track the negative influence of bad roads on the economy of rural people.

According to Berg et al. (2015), roads with the availability of good rural transport networks make the movements of agricultural produce easy and allow marketers to access markets for enhanced income and improved socio-economic development. Nearly all agricultural produce across the world is huge and quickly destroyed if not well preserved, in which Nigeria is not an exception (Yeboa, 2016). They need to be transported from where they are being produced to the place of consumption for the farmers to earn more income. Conversely, as reported by Adeniyi et al. (2018), a large number of farmers in Nigeria and most especially in Ondo State, despite every effort bring into being towards increasing agricultural output in the area, they are still facing the challenges of how to maximise income due to the problem of bad roads. Consequently, it is evident that poor road networks have much impact on farmers' income in the study area and therefore necessitate making available relevant information to government and non-governmental agencies on the need to give serious attention on how to change the strategy and transform agriculture for economic development of farmers and nations at large.

In other words, the distance between the farm location and the market results in reduced income for the farmer (Migose et al., 2018). Remoteness of farms may adversely affect the farmer's access to family work by increasing the level of competition between children's schooling and farm work. In some cases, children may have to stop going to school to help out on the farm, or they may have to go to school and the farmers have to hire expensive labour (Garner et al.,
2014). The construction of road infrastructures in rural areas in less developed nations, as well as Nigeria, is not given serious attention. This is because either it is taken as a matter of course or its direct and indirect consequences are difficult to quantify (Abur et al., 2015).

For many years, to the absolute exclusion of rural roads, the government has placed much emphasis on building, restoring, and rehabilitating roads linking intra-urban and inter-urban centers within the country (Adedeji et al., 2014). However, the government must view the rural road as an important part of the general road transport scheme. Putting them differently, they are very crucial in the growth and development of rural communities; they deserve no less attention than any other category of roads (Babatunde et al., 2014). In rural areas, the shape of nearly all laterite roads currently in existence in various countries is quite bewildering, especially during the rainy season. Roads are virtually impassable through the wet season (Olorunfemi, 2018). Poor road condition, apart from adverse effects on travellers, commodities, and traffic, often results in considerable losses of perishable agricultural produce, high moving costs of agricultural and other items, and excessive vehicle maintenance costs (Oladosu et al., 2018). All of these culminate in high transport costs that adversely affect farmers' incomes.

For the transformation of the social and economic well-being of rural communities, the condition of rural roads must be improved. It enhances the movement of people, goods, and services by connecting rural areas to different communities as well as urban centers (Ndabeni, 2016). The nature of rural roads in most of the less developed nations, such as Nigeria, is very pitiful despite its enormous contribution to the economy of the rural populace (Nwankwo and Okeke, 2017). Tunde and Adeniyi (2012) noted that where there are no access roads, the cost of transportation is very high and at the same time brings confusion about marketing, tends to reduce the level of success achieved in agricultural activities and development of the rural areas. As a result of this, the availability of good rural roads increases agricultural production, allows access to physical facilities, reduces rural people's susceptibility to frights and hurt, and promotes their build-up of livelihoods assets (Adefalu et al., 2016).

The selected local government has a large potential for agricultural resources and is one of the main food baskets in the state. This study will allow the researcher to obtain first-hand information on the income structure of these rural farmers. The study area is also characterised by some relative problems typical of the rural situation in Nigeria. The rural farmers here 
face the problems of income generation and access to finance, land policy issues, transport problems, and a host of others. The income of farmers in this study is used as a key tool for the isolation of the essential factors that should be given priority in the subsequent rural development policy. This will also lead to the implementation of government efforts to improve rural production vis-à-vis the generation of rural income in the State in general. It is against this context that the study was carried out to examine the impact of rural transportation networks on farmers' income in the Ilaje Local Government Area (LGA) of Ondo State, Nigeria. The specific objectives are to:

i) describe the socio-economic characteristics of the respondents' in the study area;

ii) identify the mode of transportation networks available and widely used in the study area;

iii) examine the perceived impact of rural transportation networks on farmers' income;

iv) determine the relationship between modes of transportation used, perceived impacts of rural transportation networks, and the level of income realised;

v) examine the constraints faced by the farmers in the study area;

vi) investigate the coping strategies on constraints in the transportation networks in the study area.

\section{Hypotheses}

i) There is no significant relationship between farmers' socio-economic characteristics and the income generated.

ii) There is no significant relationship between rural transportation impact and the income of farmers.

iii) There is no significant relationship between the forms of transportation systems used, perceived impacts of rural transportation networks, and the level of income realised.

\section{Theoretical background}

Narrative transportation theory was used in this study as the basis for designing this research. Transportation theory is concerned with the immersion of individuals within narrative content and the subsequent effects of the transportation experience (Green and Brock, 2002). More recently, many researchers have shown interest in narrative theory due to the impact narrative has on individuals' beliefs and attitudes. An analogy in the form of a journey to explain the process of transportation: Someone, 'the traveller' is transported, by some means of transportation, as a result of performing certain actions (Van Laer et al., 2014). The traveller goes some distance from his or her world of origin, which makes some aspects of the world of origin inaccessible. The traveller returns to the world of origin, somewhat changed by the journey (Green and Sestir, 2017). The "change" that occurs during the transportation experience has been a topic of particular interest; this effect has been seen as a means which alter beliefs and attitudes of the farmer on actual income realised (Price, 2017). The implication of this theory culminates in the cost of transport which has a negative or positive effect on travelers' income.

\section{MATERIAL AND METHODS}

\section{Area of study}

The study was carried out in Ilaje LGA of Ondo State. Ilaje Local Government Headquarters is Igbokoda. It covers an area of 3,000 square kilometers and a population of 289,838 (2006 population census). Traditionally, it is grouped into 9 kingdoms namely: Mahin, Ugboland, Aheri, Etikan, Obenla, Obe Ogbaro, Igbokoda, and Igbo egunrin. It falls within the wetland of the Niger-Delta of Nigeria. Its 92-kilometer coastline constitutes a significant proportion of the nation's 853-kilometer coastline. Being an interface between land and water systems, the region is ecologically complex. Ilaje is characterised by two climatic seasons, the rainy and the dry seasons. The rainy season is between March and November whereas the dry season is from late November to early March. Plantain, cassava etc are cultivated in Ilaje. The people in this area are predominantly farmers and fishing dominates farming activities of the Ilajes that live closer to the water. Also, other crops cultivated include yam, cocoyam, maize, and other food crops. Some people in these areas engage in vulcanizing, tailoring, carpentry, bricklaying, petty traders, and lumbering. The vegetation is an evergreen forest with commercial trees all over the place.

\section{Study population}

The population of the study consists of arable crop farmers in the Ilaje local government area of Ondo State.

\section{Sampling procedure and sample size}

The study employed a two-stage random sampling technique. In the first stage, twenty percent of the sixty (60) arable crop farming communities notable for being at the forefront of crop productions were randomly selected to give 12 communities from the study area. The second stage involved the random selection of 10 respondents out of 30 leading arable crop farmers from each of the 12 chosen communities with modes of transportation available in the area. In all, 120 farmers were sampled in the local government area. 


\section{Method of data collection}

Primary and secondary information sources were used to obtain data. Primary information was obtained by using a questionnaire comprising of well-structured open and close-ended questions, while secondary data were collected from the available literature.

\section{Method of data analysis}

To test the stated hypotheses, the data were analysed using descriptive statistics and inferential statistics such as chi-square and Pearson Product Moment Correlation (PPMC). The socio-economic characteristics of the respondents were presented using frequency counts, percentages, and mean. The dependent variable for this study is conceptualised as income realised by farmers which might be affected by the nature of rural transportation networks as perceived by the farmers. The respondents were to indicate their perception based on the impact of transportation through response to ten declarative statements which were rated on a five-point Likert scale and were scored 5 points for Strongly Agree (SA), 4 points for Agree (A), 3 points for Undecided (U), 2 points for Disagree (D) and 1 point for Strongly Disagree (SD) as used by Adesoji et al. (2019) and which was modified to suit the research purpose.

\section{RESULTS AND DISCUSSION}

\section{Socio-economic characteristics of respondents}

Table 1 reveals that the average age of farmers in Ondo State was 54 years, most of the respondents (80.8\%) were between 40 and 60 years of age and above. Only $5 \%$ and $14.2 \%$ of them were under 30 years of age and over 30 years of age, respectively. This implies that the increasing numbers of older farmers still discovered in agriculture strengthen the reason for the research and according to Fasina (2013), this is not a good sign of enhanced efficiency because farm production is considered to decline as they age, which could negatively affect market involvement and reduce their level of income. The majority (79.2\%) of the farmers were male and only $20.8 \%$ of them were female. This result indicates a higher percentage of males compared to females, reflecting the fact that the study area has a more male-dominated labour force in terms of crop production, which is different from what can be obtained in Sub-Saharan Africa, where about $50 \%$ of females dominated the active labour force (FAO, 2011). A low percentage of female farmers may be due to their limited access to resources and limited decision-making power compared to their male counterparts (Pionce-Gutierrez, 2016).
The results further revealed that more than half of the respondents were married ( $68.3 \%$ ), $0.8 \%$ were single, $14.2 \%$ were widowed, and $11.7 \%$ separated. More than a half, $52.5 \%$ of farmers had primary education, with $30 \%$ having secondary education and $15 \%$ having no formal education as shown in Table 1. This implies that the majority of the farmers in these areas have little enrolment in schools due to unconnected roads in the community. Mukherjee (2012) found in India that girls' attendance in schools was three times higher in villages linked by good roads than villages with bad roads. Table 1 further shows that the mean income per farming season of the farmers was 106,015 (\$293). The majority (92.4\%) of them earn between $\$ 70,000$ and $\$ 209,000$ (\$193 and \$577) per farming season. This implies a substantial percentage of the farmers' revenue had gone into transportation due to poor roads in these areas. This result is consistent with Fungo and Krygsman (2017) who have shown that poor road circumstances have impact on transport costs which hamper the production of agricultural activities, and in turn influence the income to be realised by rural farmers.

Moreover, the study revealed the mean year of experience of the farmers was 31.50 years. The majority (81.7\%) of them had between 20 and 40 years of experience. This shows that the majority of the farmers sampled have sufficient agricultural knowledge and experience that will help them to cope with the impact of rural transportation networks very well. The mean household size of the farmers was 8.0 members, with more than half of them having between 6-10 household sizes. Findings also show that the cost of transportation incurred by the respondent per month, the majority (98.3\%) spent between 100 (\$0.3) and $\$ 3900$ (\$10.8) using a motorcycle, whereas $63 \%$ of them spent more than $\$ 3600$ using vehicle depending on the distance. Also, the majority (85.0\%) and (92.5\%) of the respondents spent between 100 (\$0.3) and 3900 (\$10.8) using canoe and boat, respectively. It implies that a significant proportion of the farmers' income had gone to transportation and this is as a result of bad roads and impassable waterways in these areas. This finding is consistent with Ogunleye et al. (2018) as they confirmed that transport costs were reduced, rural demand was stimulated and rural incomes increased as a result of improved rural roads and waterways. Road quality has resulted in a significant positive contribution to production and revenue, with a $10 \%$ improvement in road and water infrastructure leading to a $12 \%$ rise in agricultural output and a $2.2 \%$ increase in overall household income. Finally, Table 1 indicates how the 
respondents are distributed according to religion. This found that $70.0 \%$ of respondents are Christians, and $25 \%$ are Muslims. Hence, Ilaje local government area is predominantly Christian communities; this is manifested in the existence of several churches in the areas.

Table 1. Distribution of Respondents according to their socio-economic characteristics $(n=120)$

\begin{tabular}{|c|c|c|c|}
\hline $\begin{array}{l}\text { Socio-economic } \\
\text { characteristics }\end{array}$ & Frequency & Percentage & \\
\hline \multicolumn{4}{|l|}{ Age } \\
\hline $20-29$ & 6 & \multicolumn{2}{|l|}{5.0} \\
\hline $30-39$ & 17 & \multicolumn{2}{|l|}{14.2} \\
\hline $40-49$ & 24 & \multicolumn{2}{|l|}{20} \\
\hline $50-59$ & 32 & \multicolumn{2}{|l|}{26.7} \\
\hline 60 and above & 41 & \multicolumn{2}{|l|}{34.1} \\
\hline \multicolumn{4}{|l|}{ Gender } \\
\hline Male & 95 & \multicolumn{2}{|l|}{79.2} \\
\hline Female & 25 & \multicolumn{2}{|l|}{20.8} \\
\hline \multicolumn{4}{|l|}{ Educational status } \\
\hline No formal education & 18 & \multicolumn{2}{|l|}{15.0} \\
\hline Primary education & 63 & \multicolumn{2}{|l|}{52.5} \\
\hline Secondary education & 36 & \multicolumn{2}{|l|}{30.0} \\
\hline Tertiary education & 3 & \multicolumn{2}{|l|}{2.5} \\
\hline \multicolumn{4}{|l|}{ Household members } \\
\hline $1-5$ & 44 & 5.8 & \multirow{3}{*}{ Mean $=8.0$} \\
\hline $6-10$ & 69 & 57.5 & \\
\hline 11 and above & 7 & 5.8 & \\
\hline \multicolumn{4}{|l|}{ Marital status } \\
\hline Single & 1 & \multicolumn{2}{|l|}{0.8} \\
\hline Married & 82 & \multicolumn{2}{|l|}{68.3} \\
\hline Divorced & 6 & \multicolumn{2}{|l|}{5.0} \\
\hline Widowed & 17 & \multicolumn{2}{|l|}{14.2} \\
\hline Separated & 14 & \multicolumn{2}{|l|}{11.7} \\
\hline \multicolumn{4}{|l|}{ Religion } \\
\hline Christian & 84 & \multicolumn{2}{|l|}{70.0} \\
\hline Islam & 30 & \multicolumn{2}{|l|}{25.0} \\
\hline Traditionalist & 6 & \multicolumn{2}{|l|}{5.0} \\
\hline \multicolumn{4}{|l|}{ Years of experience } \\
\hline $1-19$ & 16 & 18.3 & \multirow{3}{*}{$\begin{array}{l}\text { Mean }= \\
=31.50\end{array}$} \\
\hline 20-39 & 86 & 69.1 & \\
\hline 40 and above & 13 & 12.6 & \\
\hline
\end{tabular}

Cost of transportation per month(N/\$)

By motorcycle

\begin{tabular}{lrr}
$100-1900 /(0.3-5.2)$ & 83 & 69.1 \\
\hline $2000-3900 /(5.5-10.8)$ & 35 & 29.2 \\
$4000 /(11)$ and above & 2 & 1.7
\end{tabular}

\begin{tabular}{|c|c|c|c|}
\hline $\begin{array}{l}\text { Socio-economic } \\
\text { characteristics }\end{array}$ & Frequency & Percentage & \\
\hline \multicolumn{4}{|l|}{ By vehicle } \\
\hline $600-1500 /(1.7-4.2)$ & 15 & 12.5 & \\
\hline $1600-2500 /(4.4-7)$ & 27 & 22.5 & \\
\hline $2600-3500 /(7.2-10)$ & 15 & 12.5 & \\
\hline $3600 /(10)$ and above & 63 & 52.5 & \\
\hline \multicolumn{4}{|l|}{ By canoe } \\
\hline $600-1500 /(1.7-4.2)$ & 66 & 55.0 & \\
\hline $1600-2500 /(4.4-7)$ & 3 & 2.5 & \\
\hline $2600-3500 /(7.2-10)$ & 15 & 12.5 & \\
\hline $3600 /(10)$ and above & 36 & 30.0 & \\
\hline \multicolumn{4}{|l|}{ By boat } \\
\hline $600-1500 /(1.7-4.2)$ & 67 & 55.8 & \\
\hline $1600-2500 /(4.4-7)$ & 1 & 0.8 & \\
\hline $2600-3500 /(7.2-10)$ & 8 & 6.7 & \\
\hline $3600 /(10)$ and above & 44 & 36.7 & \\
\hline \multicolumn{4}{|c|}{ Income realised (N/\$) } \\
\hline $10,000-69,000$ & 16 & 3.5 & \multirow{4}{*}{$\begin{array}{c}\text { Mean = } \\
=\mathrm{N} 106,015(\$ 293)\end{array}$} \\
\hline $70,000-137,000$ & 86 & 61.7 & \\
\hline $140,000-209,000$ & 13 & 30.7 & \\
\hline 210,000 and above & 5 & 4.1 & \\
\hline
\end{tabular}

Source: Field survey, 2019

Naira to US dollar conversion rate: \$362 to \$1 US dollar

\section{Mode of transportation used by the farmers}

Table 2 shows the rural transportation network used by the farmers, about half of them (50.8\%), and $50.8 \%$ transported their farm produce using foot and motorcycle, and $49.2 \%$ of them used canoes and boats, respectively. However, $100.0 \%$ of the respondents indicated they use vehicles in transporting their produce from farms to different towns. The reason for the use of these modes of transportation is because of the bulky nature of agricultural produce. This implies that all the respondents used vehicles to transport their farm produce more than any other means of transportation in the area and thereby incurring more cost as a result of bad condition of the roads. It also indicated that they spent more money on motorcycles, canoes, and boats every month. This research is consistent with studies of Kiprono and Matsumoto (2018), who emphasised that farmers used vehicles more than any other means of transportation to transport their farm produce and this goes a long way to affect their income negatively due to poor rural transport network. 
Table 2. Rural transportation networks used by the farmers

\begin{tabular}{lcc}
\hline Transportation systems & Yes & No \\
\cline { 2 - 3 } used by the farmers' & Frequency (\%) & Frequency (\%) \\
\hline By foot & $61(50.8)$ & $59(49.2)$ \\
By bicycle & - & $120(100.0)$ \\
By motorcycle & $61(50.8)$ & $59(49.2)$ \\
By vehicle & $120(100.0)$ & - \\
By canoe & $59(49.2)$ & $61(50.8)$ \\
By boat & $59(49.2)$ & $61(50.8)$ \\
\hline
\end{tabular}

Source: Field survey, 2019

\section{Perceived impacts of rural transportation networks on farmers'}

Table 3 shows the distribution of respondents on the farmers 'incomes according to their perceived impacts of rural transport networks. Farmers perceived the quality of the transportation network causes vehicles not to be available (mean $=5.20$ ), they also felt that the quality of the transportation network discourage farmers from selling their crops (mean $=5.20)$. Farmers expressed that the quality of transportation networks leads to the damage of their crops (mean $=5.17$ ) and also affects their health status (mean $=5.14$ ). The Table further shows that more than half $(67.5 \%)$ of the farmers strongly agreed that the quality of transportation network causes a reduction in their income (mean $=5.13)$, and $62.5 \%$ indicated the quality of transportation network causes an increase in transport fares (mean $=5.12$ ). The inference is that farmers' view of transport networks presents significant problems for farmers by hindering their smooth marketing system and income. The result is consistent with Barrett et al. (2017), indicating that inadequate transportation and road infrastructure presents significant challenges by preventing the proper functioning of the market for farmers trying to purchase inputs or sell farm produce as well as for post-harvest processing and this could negatively affect market involvement and reduce their level of income.

\section{Testing of hypotheses}

The result of the analysis in Table 4 shows that there was no significant relationship between religion $\left(\chi^{2}=2.524\right.$, $p>0.05)$, educational status $\left(\chi^{2}=4.753, p>0.05\right)$, and farm income. There was, however, a significant relationship between gender $\left(\chi^{2}=6.472, p<0.05\right)$, marital status $\left(\chi^{2}=9.745, p<0.05\right)$, and farmers' income. This result implies that the farmers' income generated is irrespective of their religion and educational status, but on their gender and marital status. The implication is that the rural farmers with responsibilities (married) have a higher perception of the impacts of poor rural transportation network on their income. The predicted relationship between gender and income indicated that women are more involved in the marketing and processing of farm produce than men in African countries such as Nigeria, particularly in vegetable

Table 3. Perceived impacts of rural transportation networks on farmer's income

\begin{tabular}{lcc}
\hline \multicolumn{1}{c}{ Statement } & Mean & Rank \\
\hline The quality of transportation network causes vehicles not to be available & 5.20 & $1^{\text {st }}$ \\
\hline The quality of transportation network leads to the damage of crops & 5.17 & $3^{\text {rd }}$ \\
\hline The quality of transportation network causes a reduction in farmers' income & 5.13 & $5^{\text {th }}$ \\
\hline The quality of transportation network causes an increase in transport fares & 5.12 & $6^{\text {th }}$ \\
The quality of transportation network affects my health status & 5.14 & $4^{\text {th }}$ \\
The quality of transportation network discourages farmers from selling their crops & 5.20 & $1^{\text {st }}$ \\
The quality of transportation network encourages the selling of crops & 4.97 & $9^{\text {th }}$ \\
The present condition of the roads makes transportation of crops to the market easier & 2.48 & $10^{\text {th }}$ \\
The quality of transportation network causes a delay in transporting crops to the market & 5.01 & $7^{\text {th }}$ \\
The quality of transportation network enhance rotting of crops & 4.99 & $8^{\text {th }}$ \\
\hline
\end{tabular}

Source: Field survey, 2019

Table 4. Chi-Square analysis of the relationship between selected socio-economic characteristics of respondents and the income generated

\begin{tabular}{lccccc}
\hline Selected socio-economic characteristics & $\chi^{2}$ & $\mathbf{d f}$ & $\mathbf{c c}$ & $p$-value & decision \\
\hline Gender & 6.472 & 1 & 0.301 & $0.011^{*}$ & Significant \\
Marital status & 9.745 & 4 & 0.361 & $0.045^{*}$ & Significant \\
Religion & 2.524 & 2 & 0.193 & 0.283 & Not Significant \\
Educational status & 4.753 & 3 & 0.261 & 0.191 & Not Significant \\
\hline
\end{tabular}

*significant: $p<0.05, \chi^{2}=$ Chi-square value, $\mathrm{df}=$ degrees of freedom, $c c=$ contingency coefficient, $p$-value $=$ asymptotic significance value 
Table 5. Pearson Product Moment Correlation showing relationship between transportation networks used, perceived impacts of rural transportation network and the income realised by the respondents

\begin{tabular}{|c|c|c|c|c|}
\hline Variables & $r$-value & $p$-value & Decision & Remark \\
\hline Transportation networks used & 0.705 & $0.000^{*}$ & Significant & $\mathrm{H}_{0}$ rejected \\
\hline Perceived impacts of rural transportation & 0.267 & $0.003 *$ & Significant & $\mathrm{H}_{0}$ rejected \\
\hline
\end{tabular}

*Significant: $p<0.05$

cultivation and agricultural product marketing (Odebode, 2012). In a related study, Ayanwuyi et al. (2015) reiterated the role of gender in the income of farmers and the marketing of agricultural products. The results of the analysis in Table 5 shows that there was a significant relationship between the used transport $(\mathrm{r}=0.705, p<0.05)$ by the farmers and income generated on farming activities. The analysis shows that improved transportation would allow farmers to work harder in rural areas to increase production, add value to their products, reduce spoilage and waste, empower farmers and have a positive impact on rural productivity, income, and poverty reduction. The result aligns with the findings of Usman (2014) as they reported that transport plays an important role in the structure of food production and marketing, and that easy market transportation can make a big difference in the level of rural income. The Table further revealed a significant relationship between the farmers perceived impact of rural transportation being used $(r=0.267, p<0.05)$ by the farmers and income generated on farming activities. It means that the farmers' transportation affects their profits. Farmers use different kinds of marketing channels to market their products and each marketing channel has related costs such as transportation costs, revenues, and prices. In related studies, Yeboah (2016) and Berg et al. (2017) found that high transportation costs would discourage farmers from participating in local markets, from selling their livestock and other farm produce, focusing instead on farm gate sales, which would limit their income-generating opportunities.

\section{Constraints faced by the farmers}

Table 6 shows the unavailability of vehicles to transport crops as a serious constraint (82.5\%), and for $17.5 \%$ that it is a minor constraint. The high cost of transportation due to the quality of transport networks was a serious constraint (86.7\%), and only $13.3 \%$ indicate it as a minor constraint. This implies that the farmers were faced with the unavailability of vehicles and this has led to a rise in transport fares due to poor roads in the areas. Reduced income of farmers is a serious constraint $(70.8 \%)$ and in $29.2 \%$ was a minor constraint faced by the farmers. Damage to crops during transportation was a minor constraint in $75.0 \%$, but in $21.7 \%$ it was a serious constraint faced by the farmers. Reduced access to market was a minor constraint (64.2\%) but to some farmers it was a serious constraint $(29.2 \%)$.

\section{Coping strategies adopted by the farmers}

Table 7 shows that $60.0 \%$ of the respondents always sell at the farm gate whereas $40.0 \%$ of respondents

Table 6. Constraints faced by the farmers

\begin{tabular}{lccc}
\hline \multirow{2}{*}{$\begin{array}{l}\text { Constraints } \\
\text { Unavailability of vehicles to transport crops }\end{array}$} & $\begin{array}{c}\text { Serious } \\
\text { Constraint }\end{array}$ & $\begin{array}{c}\text { Minor } \\
\text { Constraint }\end{array}$ & Not a Constraint \\
\cline { 2 - 4 } High cost of transportation due to the quality of transport systems & Frequency (\%) & Frequency (\%) & Frequency (\%) \\
\hline Damage to crops during transportation & $99(82.5)$ & $21(17.5)$ & - \\
Reduced income of farmers & $26(86.7)$ & $16(13.3)$ & - \\
Damage to vehicles & $85(70.8)$ & $35(29.2)$ & $4(3.3)$ \\
Reduced access to market & $19(15.8)$ & $63(52.5)$ & $38(31.7)$ \\
Bad vehicles & $35(29.2)$ & $77(64.2)$ & $8(6.7)$ \\
Narrow bridges & $9(7.5)$ & $67(55.8)$ & $44(36.7)$ \\
Bad canoes & $18(15.0)$ & $33(27.5)$ & $69(57.5)$ \\
Bad boats & $17(14.2)$ & $43(35.8)$ & $59(49.2)$ \\
Long distance & $19(15.8)$ & $41(34.2)$ & $60(50.0)$ \\
\hline
\end{tabular}

Source: Field survey, 2019 
Table 7. Farmers' coping strategies

\begin{tabular}{lccc}
\hline \multirow{2}{*}{ Strategies } & Always use & Rarely use & Never use \\
\cline { 2 - 4 } & Frequency (\%) & Frequency (\%) & Frequency (\%) \\
\hline Sell at farm gate & $72(60.0)$ & $48(40.0)$ & - \\
Sell bits at a time in the market & $62(51.7)$ & $54(45.0)$ & $4(3.3)$ \\
Cooperate with other farmers to hire vehicle to market & $74(61.7)$ & $43(35.8)$ & $3(2.5)$ \\
Sell to companies & - & $1(0.8)$ & $119(99.2)$ \\
Leave crops to overgrow & - & - & $120(100.0)$ \\
Leave crops to rotten & - & - & $120(100.0)$ \\
Rescind to fate & $3(2.5)$ & $26(21.7)$ & $91(75.8)$ \\
\hline
\end{tabular}

Source: Field survey, 2019

rarely sell at the farm gate; $51.7 \%$ of the respondents always sell bits at a time in the market and $45.0 \%$ rarely sell bits at a time in the market. Thus more than a half of the farmers sell bits at a time to reduce the cost of transportation and rotting of the crops; $61.7 \%$ of the respondents always cooperate with other farmers to hire vehicles to the market whereas $35.8 \%$ of the respondents rarely cooperate with other farmers to hire vehicles to the market. Thus the cooperating farmers who shared the hired vehicles generated more income and reduced the cost of transportation than those who did not cooperate in this way.

\section{CONCLUSIONS}

It can be concluded from this study that the nature of transportation networks available in the communities under study has a significant impact on the level of income to be realised by the farmers. Based on our data, an improved transport would enable farmers to work harder for increased production in rural areas, add value to their goods, minimise spoilage and waste, motivate farmers and have a positive impact on productivity, income, jobs, and reduction of poverty in rural areas. Moreover, the results have shown that the serious constraints faced by the farmers such as the high cost of transport due to the quality of transport networks have a great influence on the income they generated. The study focused on nature and the effects of rural transportation networks on farmers' income; however, other factors affect rural farmers' incomes that have not been investigated in this research and therefore need to be investigated in future research.

\section{RECOMMENDATIONS AND POLICY IMPLICATIONS}

Local, State, and Federal transport policies should be put in place to ensure a sustainable transport system. Such a policy would underpin the already existing relationship between the transport network and the development of socio-economic activities, whereas at the same time creating a favourable transport network for further growth. The Government should open up new roads and waterways in the villages to ease the misery of the rural masses. Also, adequate storage facilities should be made available to farmers in rural areas to allow them to store and prevent the deterioration of farm produce in the event of a delayed vehicle which, in effect, increases the return of farmers. Remote communities, such as agricultural settlements in and around Ondo State, should be linked by good quality roads to improve connectivity and mobility to these areas. This will increase the use of local resources. Finally, roads connecting the market should be rehabilitated for easy transport, which would ultimately reduce the high cost of transport.

\section{CONFLICT OF INTEREST}

The author declared no conflicts of interest with respect to research, authorship and publication of this article.

\section{ETHICAL COMPLIANCE}

The authors have followed the ethical standards in conducting the research and preparing the manuscript.

\section{REFERENCES}

Abubakar A. J., Abubakar S. S., Ibrahim M. S., Kolo A. (2018): Agriculture and Poverty Reduction in Nigeria; A Review. IOSR Journal of Humanities and Social Science 23: 61-68.

Abur C. C., Ademoyewa G. R., Damkor M. (2015): Impact of rural road infrastructure on the income and productivity of household farmers in North Central Nigeria. Research Journal of Agriculture and Environmental Management 4: 451-458. 
Adedeji O. A. Olafiaji E. M. Omole F. K. Olanibi J. A., Lukman Y. (2014): An assessment of the impact of road transport on rural development: A case study of Obokun local government area of Osun State, Nigeria. British Journal of Environmental Sciences 2: 34-48.

Adefalu L. L. Olorunfemi O. D. Olatinwo L. K., Olatunji Y. (2016): Perceived Effects of Poor Road Transportation Network on Crop Production in Kaiama Local Government Area of Kwara State, North Central Nigeria. International Journal of Agricultural Management and Development 6: 497-503.

Adeniyi J. O., Akinrinmade Y., Abiodun A. L. (2018): Analysis of Road Transport Impact on Rural Development In Nigeria: A Study On Akure North Local Government Area, Ondo State. International Journal of New Technology and Research 4: 102-110.

Adesoji S. A., Famakinwa M., Eghosa A. E. (2019): Assessment of Agricultural Extension Students' Interest in Providing Private Extension Services in Nigeria. Assessment. The Journal of Agricultural Sciences-Sri Lanka 14: 57-66.

Afolabi O. J., Oluwaji O. A., Onifade T. A. (2018): Transportation Factors in the Distribution of Agricultural Produce to Urban Center in Nigeria. LOGI - Scientific Journal on Transport and Logistics 9: 1-10.

Agbigbe W. A. (2016): The Impact of Transportation Infrastructure on Nigeria's Economic Development. Ph.D. thesis, Walden University, Minnesota, United States of America.

Amare M., Cissé J. D., Jensen N. D., Shiferaw B. (2017): The Impact of Agricultural Productivity on Welfare Growth of Farm Households in Nigeria: A Panel Data Analysis. FAO. Rome. http:// www.fao.org/ 3/a-bp143e.pdf

Archer E. K., Nkambwe M. (2011): Alleviating poverty with labour-based road maintenance in the semi-arid environment of the Kgalagadi District of Botswana: Impacts and constraints. International Development Planning Review 33: 67-80.

Ayanwuyi E., Akintonde J. O., Tiamiyu A. O. (2015): Assessment of Perceived Corrupt Practices in Marketing of Agricultural Produce among Women Marketers in Ogbomoso Agricultural of Oyo State, Nigeria. International Journal of Applied Agriculture and Apiculture Research 11: 157-161.

Babatunde R. O., Adenuga A. H., Olagunju, F. I., Oladoja A. O. (2014): Effect of road infrastructure on-farm production in Oyo State, Nigeria. Ethiopian
Journal of Environmental Studies and Management 7: 197-201.

Barrett C. B., Christiaensen L., Sheahan M., Shimeles A. (2017): On the structural transformation of rural Africa. Journal of African Economies 26: 11-35.

Berg C. N., Deichmann U., Liu Y., Selod H. (2015): Transport policies and development. https://doi. org/10.1596/1813-9450-7366

Berg C. N., Deichmann U., Liu Y., Selod H. (2017): Transport Policies and Development. The Journal of Development Studies 53: 465-480.

FAO (2011): The state of food and agriculture 2010-11. Women in agriculture: Closing the gender gap for development. https://www.fao.org/publications/ sofa/2010-11/en/

Fasina O. O. (2013): Farmer's perception of the effect of aging on their agricultural activities in Ondo State, Nigeria. Venets: The Belogradchik journal for local history, cultural heritage, and folk studies 4: 371-387.

Fungo E., Krygsman S. (2017): Impact of Rural Roads Conditions on Transport Price of Agricultural Products (No. 17-03232). https://trid.trb.org/ view/1438291

Garner E., de la O Campos, A. P. (2014): Identifying the family farm. An informal discussion of the concepts and definitions, ESA Working Papers 288978, Food and Agriculture Organization of the United Nations, Agricultural Development Economics Division (ESA).

Green M. C., Brock T. C. (2002): In the mind's eye: Transportation-imagery model of narrative persuasion. In M. C. Green, J. J. Strange, \& T. C. Brock (Eds.), Narrative impact: Social and cognitive foundations (p. 315-341). Lawrence Erlbaum Associates Publishers.

Green M. C., Sestir M. (2017): Transportation theory. The International Encyclopedia of Media Effects: $1-14$.

Ikejiofor I. G., Ali A. (2014): The effects of road transport characteristics on the marketing of agricultural produce In Nsukka LGA, Enugu State, Southeastern Nigeria. Innovare Journal of Social Sciences 2: 1-4.

Kiprono P., Matsumoto T. (2018): Roads and farming: the effect of infrastructure improvement on agricultural intensification in South-Western Kenya. Agrekon 57: 198-220.

Migose S. A., Bebe B. O., de Boer I. J. M., Oosting S. J. (2018): Influence of distance to urban markets on smallholder dairy farming systems in Kenya. Tropical Animal Health and Production 50: 1417-1426.

Mukherjee M. (2012): Do Better Roads Increase School Enrollment? Evidence from a Unique Road Policy in 
India. (August 28, 2012). Available at SSRN: https:// ssrn.com/abstract=2207761 or http://dx.doi. org/10.2139/ssrn.2207761

Ndabeni L. L. (2016): An analysis of rural-urban linkages and their implications for policies that sustain development in a space continuum. South Africa: Ministry of Cooperative Governance and Traditional Affairs. 59 p.

Nduati J. K. (2017): Institutional Factors Influencing Completion of Kenya Rural Roads Authority Projects in Ruiru Sub County, Kenya. M. A. thesis, University of Nairobi, Nairobi, Kenya.

Nwankwo F. O., Okeke C. S. (2017): Rural entrepreneurship and rural development in Nigeria. Africa's Public Service Delivery and Performance Review. 5. 10.4102/apsdpr.v5il.152.

Odebode S. O. (2012): Gender issues in agricultural extension and rural development in Nigeria. Rural Development-Contemporary Issues and Practices: 141-156. DOI: 10.5772/29022

Ogunleye O., Ajibola A., Enilolobo O., Shogunle, O. (2018): Influence of road transport infrastructure on agricultural sector development in Nigeria. Logistics \& Sustainable Transport 9: 39-50.

Oladosu J. O., Kolawole O. J., Mensah F. A. (2018): The Effect of Rural Transport Infrastructure on Agricultural Productivity in Some Selected Local Governments of Oyo State. International Journal of Research in Humanities, Arts and Literature 6: 85-94.

Olorunfemi S. O. (2018): Rural Road Transportation Challenges and Food Security in Ikere-Ekiti, Ekiti State, Nigeria. Ethiopian Journal of Environmental Studies \& Management 11: 553-564.

Omollo O. G. (2015): Influence of Sustainable Maintenance of Rural Roads on Socio-Economic Activities: A Case of Households of Rongo
Constituency in Migori County, Kenya. B.Sc. project, University of Nairobi, Nairobi, Kenya.

Osabohien R., Matthew O., Gershon O., Ogunbiyi T., Nwosu E. (2019): Agriculture development, employment generation and poverty reduction in West Africa. The Open Agriculture Journal 13: 82-89.

Pionce-Gutierrez E. G. (2016): Agricultural performance in northern Ghana: a gender decomposition. M.Sc. thesis, Kansas State University, Manhattan, USA.

Price R. A. (2017): Suspenseful Narratives and Transportation; Explorations of Individual Difference Factors and Transportation as Predictors of Story-Consistent Attitudes: ETD Archive. 994.

Tunde A. M., Adeniyi E. E. (2012): Impact of road transport on agricultural development: a Nigerian example. Ethiopian Journal of Environmental Studies and Management 5: 232-238.

Usman A. B. (2014): Analysis of the condition of rural road transport in Kwara State, Nigeria. European Scientific Journal 10: 288-307.

Van Laer T., de Ruyter K., Visconti L. M., Wetzels M. (2014): The Extended Transportation-Imagery Model: A meta-analysis of the antecedents and consequences of consumers' narrative transportation. Journal of Consumer Research 40: 797-817.

Yeboah S. (2016): Influence of condition of road transport infrastructure on rural agricultural development in the Jaman South District. Ph.D. thesis, Kwame Nkrumah University of Science and Technology, Kumasi, Ghana.

Received: December 16, 2020 Accepted after revisions: January 19, 2022 